\title{
Effect of Native Soap on Insect Pests and Grain Yield of Cowpea (Vigna unguiculata (L) Walp) in Asaba and Abraka during the Late Cropping Season in Delta State, Nigeria
}

\author{
E. O. Egho ${ }^{1} \&$ E. C. Enujeke ${ }^{1}$ \\ ${ }^{1}$ Department of Agronomy, Asaba Campus Delta State University., Abraka, Nigeria \\ Correspondence: E. O. Egho, Department of Agronomy, Asaba Campus Delta State University, Abraka, Nigeria. \\ E-mail: ebenezer.egho@yahoo.com
}

Received: October 8, 2011 Accepted: March 19, 2012 Online Published: July 30, 2012

doi:10.5539/sar.v1n2p275 URL: http://dx.doi.org/10.5539/sar.v1n2p275

\begin{abstract}
Studies were conducted to test the effectiveness of native soap against cowpea insect pests during the late cowpea cropping season in two agro-ecological zones-Asaba and Abraka, Delta State. Four major insect pests, namely the cowpea aphid, Aphis craccivora Koch, the legume flower bud thrips, Megalurothrips sjostedti Tryb, the legume pod borer, Maruca vitrata Fab and pod sucking bugs were studied. The experiment was made up of five treatments-1, 2 and 3 percent concentrations of native soap, cypermethrin (as conventional chemical and check) and a control. Each treatment was replicated three times. The experiment was arranged into a randomised complete block design (RCBD). The results showed that all the major insect pests occurred in the study areas but were more at Asaba compared to Abraka. Native soap was effective against $A$. craccivora and flower bud thrips population at Asaba. Maruca vitrata was not affected by soap application. Grain yield was high at Abraka and significantly $(\mathrm{P}<0.05)$ higher than Asaba. The use of native soap as non-conventional insecticide in cowpea insect pests management appears promising, more so as it is not expensive and safe to handle. Farmers may prefer it to synthetic chemical pesticides with their associated dangers.
\end{abstract}

Keywords: native soap, cowpea, insect pests, late season, Asaba/Abraka

\section{Introduction}

Cowpea (Vigna unguiculata) (L.) (Walp) is a major food crop cultivated in the tropical and subtropical regions of the world. It is well grown in Nigeria, mainly in the Sudan savannah belts (Rachie, 1985). Its cultivation lately continued to southern Nigeria and is being successfully produced in the east and west (Ejiga, 1979; FOS, 1995). The crop serves various purposes to man-as protein, derived from the grains (IITA, 1984); it is rich in vitamins, mineral salts and fats. It is important as fibre crop (Rachie, 1985) in erosion control (Okigbo, 1978) and livestock industries (Job et al., 1983). In some African communities, it is consumed as vegetable (Duke, 1981). Because of its usefulness and the ever-growing demand, partly due to human population growth, it has become necessary to improve and increase production. Presently, grain yield at the farm level is abysmally low (Omongo et al., 1997) and in Africa generally. Consequently, all factors that have adverse effect on its growth are being carefully studied.

Among the several production constraints of cowpea, the activities of insect pests and diseases, while in the field have been clearly recognised as major limiting factors in cowpea growth (Asiwe, 2005, 2009) Insect-pests attack and damage the crop at all growth stages (Jackai et al., 1988) and yield losses due to their activities is about 70 percent (Edema \& Adipala, 1996 ). These insects include (i) the cowpea aphid, Aphis craccivora, Koch which attacks the seedlings, flowers and pods (ii) the flower bud thrips, Megalurothrips sjostedti Tryb which attacks the flower buds and flowers (iii) the legume pod borer, Maruca vitrata Fab (Karungi et al., 2000) which damages the flowers, young stems, cowpea pods and seeds and (iv) a complex of pod sucking bugs such as Clavigralla tomentosicollis Stal, Anoplocnemis curvipes Fab and Aspavia armigera Fab. (Karugi et al., 2000)

Without their control, no meaningful grain yields is obtained (Ramison, 2005). Various methods of control are however available (Jackai, 1993) but the most reliable one is the use of synthetic chemical pesticides (Ayoade, 1975) and yield several folds have been recorded (Jackai, 1993). Sometimes, however, commercial cowpea farmers over spray their farms-from 8 to 10 times (Omongo et al., 1997). Excessive and unwise use of 
conventional chemicals have adverse effect on the users and consumers; kills non-target organisms (e.g. pollinators, predators, parasites and parasitoids and ultimately pollute the environment (Alabi et al., 2003). In order to minimise the use of synthetic chemicals, other control measures that are environmentally friendly are presently being advocated. A recently introduced method is the application of non-conventional chemicals, plant products/ extracts that are insecticidal in nature. Many of such products like neem seed kernel extract (Jackai, 1993; Emosairue \& Ubana, 1998; Okparaeke et al., 2006; Egho, 2010), have been identified. Soaps generally, kill small insects by contact and native soap has been reported effective against aphids (Illiyasu, 2004).

This study, investigates the potential in native soap in the management of the field key insect pests of cowpea in two locations-Asaba and Abraka during the late cropping season.

\section{Materials and Methods}

Two study sites were chosen for the experiments-Asaba, the first site is situated in the northern part of Delta State, occupying longitude $06 \mathrm{o} 4^{\prime} \mathrm{N}$ and latitude $064^{\prime} 9^{\prime} \mathrm{E}$. The area experiences drier weather. The mean annual rainfall, temperature and relative humidity in 2005 were $163.70 \mathrm{~mm}, 28.81^{\circ} \mathrm{C}$ and $80.41(\%)$ respectively. Abraka, the second site is located on longitude $05^{\circ} 47 \mathrm{~N}$ and latitude $06006^{\prime} \mathrm{E}$ with mean annual rainfall, temperature and relative humidity of $232.46 \mathrm{~mm}, 30.51{ }^{\circ} \mathrm{C}$ and $83.00(\%)$ respectively. The region is located southwardly, closer to the Niger Delta with frequent rainfall. Both locations are about 135 kilometres apart. The land at both locations was prepared with hoes and shovels. Experimental beds measured each $3 \times 5 \mathrm{~m}$ with $1.5 \mathrm{~m}$ as inter-plot. Ife brown seed variety were planted in each plot at planting space of $60 \times 30 \mathrm{~cm}$ (Remison, 1978e). Planting at Asaba took place on the 17th September 2005 and Abraka, on 29th September, 2005. Each experimental plot consisted of 6 rows of 36 plants. The chemical applied on the crops was native soap. Three concentrations $-1,2$ and 3 percent concentrations (non-phytotoxic concentrations)_were made by weighing 10, 20 and 30 grams of soap and dissolving each weight in $100 \mathrm{ml}$ of water. The mixture was left overnight and then filtered with a muslin cloth after stirring for some minutes. Chemical application commenced 25 days after planting (DAP) and continued for 5 times at 7 days' intervals. The experiment consisted of five treatments and three replications fitted into a randomised complete block design (RCBD). The treatments were 1,2 and 3 percent soap concentrations, cypermethrin (as check) and a control.

\subsection{Insect Observation and Data Collection}

Impact of chemical application on four major insect pests of cowpea was assessed as follows:

Aphis craccivora: Commencing from 26 days after planting (DAP), the colony size of A. craccivora was assessed weekly between 8 and 10 a.m. From the two middle rows of each cowpea plot, twenty stands were tagged randomly. Each stand was then carefully inspected for infestation and visually scored on a scale of 10 points (Table 1). Six observations were made and the mean score calculated.

Table 1. Scale for rating aphid infestation on cowpea

\begin{tabular}{lll}
\hline Rating & Number of aphids & Appearance \\
\hline 0 & 0 & no infestation \\
1 & $1-4$ & a few individual aphids \\
3 & $5-20$ & a few isolated colonies \\
5 & $21-100$ & several small colonies \\
7 & $101-500$ & large isolated colonies \\
9 & $>500$ & large continuous colonies \\
\hline
\end{tabular}

Source: Litsinger et al. (1977)

Megalurothrips sjostedti: Damage to cowpeas by M. sjostedti was determined between 8 and 10 a.m. when the plants were 30 days old. Assessment was based on damage symptoms such as browning/drying of stipules, leaf or flower buds and bud abscission. Twenty stands in the two middle rows of each plot were randomly tagged and damage in each stand was visually rated on a scale of 1-9 points (Table 2). The mean score was then calculated and recorded. Four observations at 6 days' intervals were made. 
Table 2. Scale for rating flower bud thrips infestation on cowpea

\begin{tabular}{|c|c|}
\hline Rating & Appearance \\
\hline 1 & no browning/drying (i.e. scaling) of stipules, leaf or flower buds; no bud abscission \\
\hline 3 & initiation of browning of stipules, leaf or flower buds; no bud abscission \\
\hline 5 & distinct browning/drying of stipules and leaf or flower buds; some bud abscission \\
\hline 7 & $\begin{array}{l}\text { serious bud abscission accompanied by browning/drying of stipules and buds; non elongation of } \\
\text { peduncles }\end{array}$ \\
\hline 9 & $\begin{array}{l}\text { very severe bud abscission, heavy browning, drying of stipules and buds; distinct non-elongation of } \\
\text { (most or all) peduncles. }\end{array}$ \\
\hline
\end{tabular}

Source: Jackai and Singh, 1988.

Maruca vitrata: M. vitrata damage to flowers was carried out in the field between 3 and 5 p.m. when the plants were 45 days old. Twenty flowers in the two outer rows of each plot were selected randomly and each was opened and carefully examined on the spot for damage. The presence of larva or holes on the flower was used as the damage index. The number of flower bud thrips in each flower was also recorded when the flower was opened. Four observations were made at 5 days' intervals. Mean score for the observations were then calculated and recorded.

Pod sucking bugs (PSBs): The number of PSBs that rested on cowpeas in the two middle rows of each plot was counted between 8 and 10 a.m. when the cowpeas were 45 days after planting (DAP). All PSBs were counted together because they do similar damage. PSBs beyond the nymphal phase were counted together. Four observations were made at intervals of 6 days.

\subsection{Yield and Yield Related Components}

Grain yield: This was assessed when the pods were fully ripe at the age of 65-70 days after planting. Pods from the two middle rows of each cowpea plot were harvested and kept in black polythene bags according to treatments. They were then sun-dried for seven days and shelled. The grains from the different treatments were weighed with a balance -triple beam balance (Haus model) and the various weights recorded.

Seed weight: Seed weight was determined from 100 grains. From each treatment, 100 seeds were picked and weighed using triple beam balance. The various weights were then recorded.

Number of pods per plant: This was determined in the field when the pods were 65 days old. One metre long distance was marked out with two sticks from the two middle rows of each plot. All the pods and their stands that fell within this distance were counted. The number of pods were then divided by the number of stands to give number of pods per plant.

Number of pods/plant $=$ Number of pods $/$ Number of stands

Pod load (PL) and Pod damage (PD) by Maruca vitrata: Assessment was made in the field at the age of 60 days when the pods were partially matured but still green. Pod load and pod damage were determined by visual rating on a scale of 1-9 points (Table 3). Maruca vitrata damage index were holes and frass on pods and sticking together of pods (Jackai \& Singh, 1988).

Table 3. Scale for rating Maruca vitrata damage to cowpea

\begin{tabular}{lccc}
\hline & \multicolumn{2}{c}{ Pod load (PL) } & \multicolumn{2}{c}{ Pod damage (PD) } \\
\hline Rating Degree of podding & Rating & $\%$ \\
1 & most $(<60 \%$ peduncles bare (i.e. no pods) & 1 & $0-10$ \\
3 & $31-50 \%$ peduncles bare & 2 & $11-20$ \\
& & 3 & $21-30$ \\
5 & $16-30 \%$ peduncles bare & 4 & $31-40$ \\
& & 5 & $41-50$ \\
7 & Up to 15\% peduncles bare & 6 & $51-60$ \\
& & 7 & $61-70$ \\
9 & Occasional bare peduncles & 8 & $71-80$ \\
\hline
\end{tabular}

Source: Jackai and Singh, 1988. 
Pod length: Pod length was determined in the laboratory by measurement. Twenty pods were randomly hand-picked from well-dried pods kept in polythene bags, labelled according to treatments. Each pod was then measured with a flexible thread. The mean value for the twenty pods was then calculated and recorded.

Seed damage: Damage to seeds was assessed in the biology laboratory. Matured pods at the age of 65 DAP were harvested from the two middle rows of each plot into black polythene bags (labelled according to treatments). The pods were sun-dried for one week and from each bag, 20 pods were randomly picked with hand. Each pod was carefully opened to expose the seeds. These were counted per pod and the number recorded. The seeds in each pod were classified into aborted seeds per pod, wrinkled seeds per pod and seeds with feeding lesions per pod. The mean value for the number of seeds per pod and classified seeds were calculated and recorded.

Pod evaluation index (Ipe): Assessment was made with the formula below:

PL x (9 - PD) where PL is pod load and PD, pod damage (Jackai \& Singh, 1988).

Data for insect observation, yield and yield related components were subjected to analysis of variance (ANOVA) and significant means separated by Fisher's Least Significant Difference Test (LSD), at 5\% level of significance.

\section{Results}

In the late season experiment, the major insect pests of cowpea were recorded at Asaba (Table 4). The soap concentration at two (2) and three (3) percent (non-phytotoxic) significantly $(\mathrm{P}<0.05)$ reduced $A$. craccivora when compared with control. At $1 \%$ concentration, the insect was slightly reduced. On M. sjostedti, no significant difference among the treatments was recorded. However, one percent concentration recorded slightly less cowpea damage when compared with the unprotected crops. The one percent soap concentration significantly $(\mathrm{P}<0.05)$ reduced flower bud thrips population compared to control. Furthermore, the two and three percent concentration slightly controlled the insects when compared with the unprotected crops. With $M$. vitrata, the soap treatment did not reduce the insect compared to the control plots. None of the soap treatments was significantly affected in reducing pod sucking bugs (PSBs).

Table 4. Effect of application of native soap on the major insect pests of cowpea in the late season at Asaba (Egho \& Emosairue, 2010)

\begin{tabular}{|c|c|c|c|c|c|}
\hline Treatments & $\begin{array}{l}\text { Aphis craccivora } \\
\text { (rating)** }\end{array}$ & $\begin{array}{l}\text { Megalurothrips } \\
\text { sjostedti (rating) }\end{array}$ & $\begin{array}{l}\text { Flower bud thrips } \\
\text { (actual counting) }\end{array}$ & $\begin{array}{l}\text { Maruca vitrata* } \\
\text { (actual counting) }\end{array}$ & $\begin{array}{l}\text { PSB } * * \\
\text { (actual counting) }\end{array}$ \\
\hline CONTROL & 1.89 & 1.33 & 8.30 & 0.05 & 3.89 \\
\hline $1 \%$ & 1.06 & 1.17 & 5.28 & 0.08 & 3.56 \\
\hline $2 \%$ & 0.67 & 1.33 & 6.29 & 0.10 & 2.00 \\
\hline $3 \%$ & 0.22 & 1.50 & 5.98 & 0.08 & 2.78 \\
\hline CPM & 0.44 & 1.17 & 2.96 & 0.03 & 9.56 \\
\hline $\operatorname{LSD}(0.05)$ & 0.93 & NS & 2.48 & 0.04 & 3.10 \\
\hline
\end{tabular}

* Means of 20 flowers, ${ }^{* *}$ Number per 2-middle rows, CPM - Cypermethrin

All the major insect pests were observed during the late cropping season at Abraka (Table 5). A. craccivora was not significantly $(\mathrm{P}>0.05)$ reduced at any of the soap protected plots compared to control. There were no significant differences among the various treatments for $M$. sjostedti, flower bud thrips population, $M$. vitrata and pod sucking bugs. 
Table 5. Effect of application of native soap on the major insect pests of cowpea in the late season at Abraka (Egho, 2011)

\begin{tabular}{lccccc}
\hline $\begin{array}{c}\text { Treatments } \\
\text { (rating)** craccivora }\end{array}$ & $\begin{array}{c}\text { Megalurothrips } \\
\text { sjostedti (rating) }\end{array}$ & $\begin{array}{c}\text { Flower bud thrips* } \\
\text { (actual counting) }\end{array}$ & $\begin{array}{l}\text { Maruca vitrata* } \\
\text { (actual counting) }\end{array}$ & $\begin{array}{c}\text { PSB** } \\
\text { (actual counting) }\end{array}$ \\
\hline CONTROL & 2.22 & 1.00 & 2.41 & 0.09 & 0.11 \\
$1 \%$ & 1.72 & 1.00 & 2.31 & 0.03 & 0.00 \\
$2 \%$ & 2.17 & 1.00 & 2.14 & 0.06 & 0.00 \\
$3 \%$ & 2.22 & 1.00 & 1.97 & 0.17 & 0.00 \\
CPM & 1.06 & 1.00 & 1.94 & 0.31 & 0.00 \\
LSD $(0.05)$ & 0.67 & $\mathrm{NS}$ & $\mathrm{NS}$ & $\mathrm{NS}$ & $\mathrm{NS}$ \\
\hline
\end{tabular}

* Means of 20 flowers, ** Number per 2-middle rows, CPM-Cypermethrin

Table 6. The location effect of the application of native soap on the major insect pests of cowpea in the late season at Asaba and Abraka.

\begin{tabular}{lccccc}
\hline Season & $\begin{array}{l}\text { Aphis craccivora } \\
\text { (rating) }\end{array}$ & $\begin{array}{l}\text { Megalurothrips } \\
\text { sjostedti (rating) }\end{array}$ & $\begin{array}{l}\text { Flower bud thrips* } \\
\text { (actual counting) }\end{array}$ & $\begin{array}{l}\text { Maruca vitrata* } \\
\text { (actual counting) }\end{array}$ & $\begin{array}{c}\text { PSB }^{* *} \\
\text { (actual counting) }\end{array}$ \\
\hline Asaba Late & 0.86 & 1.30 & 5.76 & 0.07 & 6.72 \\
Abraka Late & 1.88 & 1.00 & 2.15 & 0.13 & 0.06 \\
LSD (0.05) & 0.17 & 0.13 & 0.57 & NS & 1.16 \\
\hline
\end{tabular}

* Means of 20 flowers, ${ }^{* *}$ Number per 2 middle rows, NS-Not significant

Table 7. Effect of native soap and cypermethrin on yield and yield related components from cowpea in the late season at Asaba (Egho \& Emosairue, 2010)

\begin{tabular}{|c|c|c|c|c|c|c|c|c|c|c|c|}
\hline Treatments & $\begin{array}{c}\text { Dry } \\
\text { Grain } \\
\text { yield (kg } \\
\left.\text { ha }^{-1}\right)\end{array}$ & $\begin{array}{c}100 \\
\text { seeds } \\
w t(g)\end{array}$ & $\begin{array}{c}\text { Number } \\
\text { of pods/ } \\
\text { plant } \\
\text { (approx) }\end{array}$ & $\begin{array}{l}\text { Pod } \\
\text { length } \\
(\mathrm{cm})\end{array}$ & $\begin{array}{l}\text { Number of } \\
\text { seeds/pod }\end{array}$ & $\begin{array}{l}\text { Pod } \\
\text { load }\end{array}$ & $\begin{array}{c}\text { Pod } \\
\text { damage }\end{array}$ & $\begin{array}{c}\text { Pod } \\
\text { evaluation } \\
\text { index }\end{array}$ & $\begin{array}{c}\text { Aborted } \\
\text { seeds/pod }\end{array}$ & $\begin{array}{l}\text { Wrinkled } \\
\text { seeds/pod }\end{array}$ & $\begin{array}{c}\text { Seeds } \\
\text { with } \\
\text { feeding } \\
\text { lesions }\end{array}$ \\
\hline CONTROL & 20.33 & 5.23 & 3.13 & 6.47 & 3.22 & 2.33 & 8.33 & 2.00 & 0.62 & 2.02 & 0.00 \\
\hline $1 \%$ & 33.66 & 6.53 & 3.68 & 6.46 & 4.48 & 4.33 & 6.00 & 18.33 & 0.62 & 1.28 & 0.02 \\
\hline $2 \%$ & 15.11 & 3.67 & 2.37 & 5.07 & 3.35 & 3.67 & 7.33 & 7.67 & 0.25 & 1.27 & 0.05 \\
\hline $3 \%$ & 19.33 & 5.10 & 3.66 & 8.49 & 6.27 & 4.33 & 6.00 & 14.33 & 0.13 & 2.60 & 0.03 \\
\hline CPM & 158.55 & 11.67 & 7.99 & 12.73 & 9.50 & 9.00 & 2.00 & 63.00 & 0.92 & 3.65 & 0.02 \\
\hline $\operatorname{LSD}(0.05)$ & NS & NS & 3.37 & NS & 5.62 & 3.19 & 3.15 & 17.91 & NS & 2.04 & NS \\
\hline
\end{tabular}

CPM-Cypermethrin

The data for the effect of location on the major insect pests of cowpea under the application of native soap in the late season are presented in Table 6.

A. craccivora infestation was more at Abraka and significantly $(\mathrm{P}<0.05)$ higher than Asaba location. For $M$. sjostedti damage to cowpea, flower bud thrips population and coreid bug infestation, their occurrence were more in Asaba and significantly $(\mathrm{P}<0.05)$ higher than Abraka location. In the case of pod borer damage, there was no significant difference at both locations. However, the damage was slightly more in Abraka than Asaba.

Grain yields from all the treatments in the late cropping season were generally low at Asaba (Table 7). There was no significant $(\mathrm{P}>0.05)$ difference among the soap treated plots and when compared to control. On yield related components, number of pods/plant, number of seeds/pods, pod load, pod damage, pod evaluation index and wrinkled seeds/pod showed significant differences among the treatments. Conversely, there was no significant difference in 100 seed weight, pod length, aborted seeds/pod and seeds with feeding lesions in the various treatments. 
At Abraka, grain yields were moderately high in all the soap treatments (Table 8). However, the soap treatments were not significantly different and when compared with control. Grain yield in cypermethrin treated plots significantly $(\mathrm{P}<0.05)$ produced yield compared to the other treatments. Yield related components such as 100 seeds weight, number of pods/ plant and seeds with feeding lesions did not show significant difference among the treatments; there were significant differences in all other yield related components in the different treatments.

Table 8. Effect of native soap and cypermethrin on yield and yield related components from cowpea in the late season at Abraka (Egho, 2011)

\begin{tabular}{|c|c|c|c|c|c|c|c|c|c|c|c|}
\hline Treatments & $\begin{array}{c}\text { Dry } \\
\text { Grain } \\
\text { yield } \\
(\mathrm{kg} \\
\left.\mathrm{ha}^{-1}\right)\end{array}$ & $\begin{array}{c}100 \\
\text { seeds } \\
\text { wt(g) }\end{array}$ & $\begin{array}{c}\text { Number } \\
\text { of pods/ } \\
\text { plant } \\
\text { (approx) }\end{array}$ & $\begin{array}{c}\text { Pod } \\
\text { length } \\
(\mathrm{cm})\end{array}$ & $\begin{array}{l}\text { Number } \\
\text { of } \\
\text { seeds/pod }\end{array}$ & $\begin{array}{l}\text { Pod } \\
\text { load }\end{array}$ & $\begin{array}{c}\text { Pod } \\
\text { damage }\end{array}$ & $\begin{array}{c}\text { Pod } \\
\text { evaluation } \\
\text { index }\end{array}$ & $\begin{array}{c}\text { Abor } \\
\text { seeds/ }\end{array}$ & 1 & $\begin{array}{l}\text { Seeds } \\
\text { with } \\
\text { feeding } \\
\text { lesions }\end{array}$ \\
\hline ONTROL & 374.30 & 17.67 & 8.63 & 13.17 & 10.35 & 3.00 & 6.33 & 10.67 & 0.0 & 1.0 & $0.0^{7}$ \\
\hline$\%$ & 510.10 & 16.87 & 6.81 & 13.49 & 10.90 & 6.67 & 2.67 & 42.00 & 0.1 & 0.5 & 0.1 \\
\hline $2 \%$ & 358.90 & 17.00 & 8.39 & 12.98 & 9.85 & 4.33 & 3.33 & 26.33 & 0.0 & 0. & 0.15 \\
\hline $3 \%$ & 570.80 & 17.47 & 9.62 & 13.44 & 0.97 & 5.33 & 2.67 & 34.67 & 0.07 & 0.6 & 0.10 \\
\hline CPM & 847.20 & 16.57 & 7.29 & 13.33 & 11.28 & 9.00 & 1.33 & 69.00 & 0.3 & 0.1 & 0.02 \\
\hline $\operatorname{LSD}(0.05)$ & 486.82 & NS & NS & 0.49 & 1.21 & 4.31 & 2.34 & 30.56 & 0.19 & 0.66 & NS \\
\hline
\end{tabular}

CPM-Cypermethrin

Table 9. The location effect on cowpea yield and yield related components under the application of native soap in the late season at Asaba and Abraka

\begin{tabular}{|c|c|c|c|c|c|c|c|c|c|c|}
\hline Season & $\begin{array}{cc}\text { Dry } & \\
\text { Grain } & 100 \\
\text { yield } & \text { seeds } \\
(\mathrm{kg} & \mathrm{wt}(\mathrm{g}) \\
\left.\mathrm{ha}^{-1}\right) & \end{array}$ & $\begin{array}{c}\text { Number } \\
\text { of pods/ } \\
\text { plant } \\
\text { (approx) }\end{array}$ & $\begin{array}{l}\text { Pod } \\
\text { load }\end{array}$ & $\begin{array}{l}\text { Pod } \\
\text { length }\end{array}$ & $\begin{array}{c}\text { Pod } \\
\text { damage }\end{array}$ & $\begin{array}{c}\text { Pod } \\
\text { evaluation } \\
\text { index }\end{array}$ & $\begin{array}{c}\text { No. of } \\
\text { Seeds } \\
\text { per } \\
\text { pod }\end{array}$ & $\begin{array}{c}\text { Aborted } \\
\text { seeds/pod }\end{array}$ & $\begin{array}{c}\text { Wrinkled } \\
\text { seeds/pod }\end{array}$ & $\begin{array}{l}\text { Seeds with } \\
\text { feeding } \\
\text { lesions }\end{array}$ \\
\hline Asaba Late & $49.40 \quad 6.44$ & 3.97 & 4.73 & 7.84 & 5.93 & 21.07 & 5.36 & 0.71 & 2.16 & 0.02 \\
\hline Abraka Late & 532.3017 .11 & 8.15 & 5.67 & 13.28 & 3.27 & 36.53 & 10.67 & 0.14 & 0.37 & 0.10 \\
\hline $\operatorname{LSD}(0.05)$ & 211.911 .91 & 0.97 & NS & 1.56 & 0.91 & 7.82 & 1.32 & NS & 0.66 & NS \\
\hline
\end{tabular}

NS $=$ Not significant

The results of the effect of location on yield and yield related components in the late season are presented in Table 9. Grain yield were significantly $(\mathrm{P}<0.05)$ higher at Abraka compared to Asaba. One hundred seed weight, number of pods per plant, pod length, pod evaluation index and number of seeds per pod were all significantly $(\mathrm{P}<0.05)$ higher at Abraka than Asaba. However, pod damage and wrinkled seeds per pod was significantly higher at Asaba than Abraka. There were no differences in pod load, aborted seeds per pod and seeds with feeding lesions in the two locations. However, in terms of pod load, Abraka had means (5.67) that was slightly higher than Asaba (4.73).

\section{Discussion}

All the major insect pests were observed on cowpea during the late cropping season at both locations. When compared with early season insect pests (Egho, 2010), more insect pests were recorded in the late than early season. In particular, A. craccivora, $M$. sjostedti and pod sucking bugs occurred predominantly more during the late season at both locations than early season cowpea planting. The present study gives support to the above reports. The study has indicated that less rainfall and warm weather as experienced in the months of August to October are possible factors which favour the activities of A. craccivora, $M$. sjostedti and pod sucking bugs.

On the insecticidal potential of native soap, the study showed that soap was effective against $A$. craccivora and flower bud thrips population at Asaba. M. vitrata was not affected by soap application. This may be connected with the behaviour of this insect which usually makes it to hide in tunnels, in pods, seeds and flowers or detoxify chemicals (Jackai, 1983). The various soap concentrations reduced pod sucking bug population at Asaba. Similar situation was observed for all the major insect pests at Abraka, under soap application. Soap as tool for insect 
pests management has been successfully used for several decades in some parts of the world on aphids on some fruits and grass house. Other minute insects such as mealybugs and psyllids and arachnids, e.g. spiders and mites have been controlled by soap sprays. Indeed, the effectiveness of soap in cowpea production has been reported by IITA (2002) that the cowpea variety IT 90K-277-2 under soap application gave yield of $516 \mathrm{~kg} \mathrm{ha}^{-1}$ compared to $361 \mathrm{~kg} \mathrm{ha}^{-1}$ without insecticide. Similarly, insect pests on cowpea during the early cropping season at Asaba were controlled using native soap (Egho \& Emosairue, 2010). Also, similar reports of effectiveness of soap on cowpea insect pests in Zaria was given by Illiyasu (2004). Soaps kills insect by contact and it must sufficiently wet the plant on application. On phytotoxicity, a concentration of 1-3 percent is recommended, above this it becomes phytotoxic. The study noted that insects occurrence was not uniform in the study areas- $A$. craccivora and $M$. sjostedti damage, flower bud thrips population and pod sucking bugs were more at Asaba than Abraka, while only Maruca vitrata occurred more in Abraka compared to Asaba. This tends to suggest that more insect damage may occur at Asaba compared to Abraka. The variation in insect occurrence observed in the two locations may be due to prevailing weather factors or insect build up resulting from cowpea, inconsistently cultivated earlier in Asaba agro-ecological zone, before the study was conducted.

Cowpea grain yield was unusually low at Asaba in all the treatments. There was sudden cessation of rain in the months of September and October and this perhaps was responsible for poor plant growth, leading to poor podding and pod filling. For better plant growth, cowpea cultivation in the late season should be carried out in the month of August. However, the situation was different at Abraka; all the soap treatments moderately produced grains of $510.10 \mathrm{~kg} \mathrm{ha}^{-1}, 358.9 \mathrm{~kg} \mathrm{ha}^{-1}$ and $590.80 \mathrm{~kg} \mathrm{ha}^{-1}$ from $1 \%, 2 \%$ and $3 \%$ concentrations respectively.

Cowpea grain yield was significantly $(\mathrm{P}<0.05)$ higher at Abraka $\left(532.30 \mathrm{~kg} \mathrm{ha}^{-1}\right)$ compared to Asaba $(49.40 \mathrm{~kg}$ ha-1). The difference in grain yield perhaps is due to weather variations in the two locations. Yield difference due to location effect for crops such as cassava (Akparobi et al., 2002), maize (Agbogidi, 2006) and yam (Tobih, 2007) have earlier been reported. The grain yield at Abraka in the late season, compares favourably with grain yield from some of the cowpea producing zones of Nigeria such as Samaru, Kano and Ilora (IITA, 1986), Bida and Mokwa (Afun et al., 1991) and Bauchi (Degri \& Hadi, 2000).

The study noted that cowpea cultivation in Abraka would be profitable to farmers judging from the grain yield. The main weapon for management of insect pests on crops all over the years has been the use of synthetic chemical pesticides (Jackai, 1993). However, awareness of environmental pollution, toxicity to mammals, residues in crops and destruction of non-target organisms (Afun et al., 1991; Alabi et al., 2003) due to chemical application has led to their condemnation. Consequently, ecological and integrated pest management (IPM) approach and use of non-conventional chemical that are devoid of the dangers associated with conventional chemicals are presently being explored by farmers. Native soap-non conventional chemical (plant derivative) successfully reduced the activities of major insect pests of cowpea (except Maruca) during the late season in the study areas, though soap was observed to cause delay in cowpea flowering. Moreover, the grain yield recorded at Abraka is indicative of soap as reliable biopesticide.

This study is preliminary report on the potential of native soap as an insecticide and calls for further investigation.

\section{References}

Afun, J. V. K., Jackai, L. E. N., \& Hodgson, C. J. (1991). Calendar and monitored insecticide application for the control of cowpea pests. Crop Protection, 10, 363-370. http://dx.doi.org/10.1016/S0261-2194(06)80025-6

Agbogidi, M. O. (2006). Effects of soil contamination with crude oil on the growth and yield of maize (Zea mays L) in Delta State. Ph.D thesis, Delta State University, Abraka

Akparobi, S. O., Togun, A. O., Ekanayake, I. J., \& Dris, R. (2002). Effects of low temperatures on dry matter partitioning and yield of cassava clones. Tropical Science, 42(1), 22-29.

Alabi, O. Y., Odebiyi, J. A., \& Jackai, L. E. N. (2003). Field evaluation of cowpea cultivars (Vigna unguiculata (L) Walp.) for resistance to flower bud thrips (Megalurothrips sjostedti Trybom) Thysanoptera: Thripidae). International Journal of Pest Management, 49(4), 287-291. http://dx.doi.org/10.1080/0967087031000123706

Asiwe J. A. N., Nokoe, S., Jackai, L. E. N., \& Ewete, F. K. (2005). Does varying cowpea spacing provide better protection against cowpea pests? Crop protection, 24, 465-471. http://dx.doi.org/10.1016/j.cropro.2004.09.014

Asiwe, J. A. N. (2009). Insect mediated outcrossing and geneflow in cowpea Vigna unguiculata (L.) Walp: 
implication for seed production and provision of containment structures for GT Cowpea. Afri. J. Biotechnol, $8(2), 226-230$.

Ayoade, K. A. (1975). Recent trends in chemical control of the insect pest complex of cowpea in Western Nigeria. In: Proc. IITA collaborators' meeting on Grain Legume Improvement, 9-13 June, International Institute of tropical Agriculture, Ibadan, Nigeria. pp. 44-51.

Edema, R., \& Adipala, E. (1996). Effect of crop protection management practice on yields of seven cowpea varieties in Uganda . Int. J. Pest Manage, 42, 317-320. http://dx.doi.org/10.1080/09670879609372013

Degri, M. M., \& Hadi, H. M. (2000). Field evaluation and economies of some insecticides against the major insect pests of cowpea (Vigna unguiculata (WALP) in Bauchi, Nigeria. ESN Occasional Publication, 32, 113-118.

Duke, J. A. (1981). Vigna unguiculata (L) Walp. Spp unguiculata In: legumes of world economic importance. Plenum Press, New York, USA. pp. 303-305.

Egho, E. O. (2010). Comparative studies on insect species of cowpea (Vigna unguiculata) (L) Walp) in two agro-ecological zones during the early cropping season in Delta State, Southern Nigeria. Agriculture and Biology Journal of North America, 1(5), 946-949.

Egho, E. O. (2011). Evaluation of native soap (black soap) for the control of major insect pests and yield of cowpea (Vigna unguiculata) (L.) Walp) in Abraka, Delta State, Nigeria. Nigeria Journal of Science and Environment, Faculty of Science, Delta State University, Abraka.

Egho, E. O., \& Emosairue, S. O. (2010). Evaluation of native soap (local black soap) for the control of major insect pests and yield of cowpea (Vigna unguiculata) (L) Walp) in Asaba, Southern Nigeria. Agriculture and Biology Journal of North America, 1(5), 938-945.

Ejiga, N. O. (1979). The efficiency of the indigenous food grain marketing systems in Nigeria. Savannah Dec., 8 (2), 70-83.

Emosairue, S. O., \& Ubana, U. B. (1998). Field evaluation of neem for the control of some cowpea insect pests in Southern Nigeria. Global Journal of Pure and Applied Science, 4, 237-241.

FOS. (1995). Annual Abstract of statistics, Lagos, Nigeria.

IITA. (1984) .Annual Report for 1982. Ibadan, Nigeria.

IITA. (1986). Annual report for 1985, Grain Legume Improvement Program, Ibadan, Nigeria.

IITA. (2002). Improving and intensifying cereal-legume systems in the moist and dry savannas of the West and Central Africa. Annual Report 2002. IITA, Ibadan. p. 23.

Iliyasu, A. S. (2004). Evaluation of efficacies of some foliar applied botanicals on the control of aphids (Aphis craccivora Koch (Homoptera: Aphididae) on cowpea. M.Sc. dissertation, Ahmadu Bello University, Zaria, Nigeria.

Jackai, L. E, N., Roberts, J. M. F., \& Singh, S. R. (1988). Cowpea seed treatment with carbosulfan potential for control of seedling pests. Crop Protection, 7, 384-390. http://dx.doi.org/10.1016/0261-2194(88)90007-5

Jackai, L. E. N. (1983). Efficacy of insecticide applications at different times of day against the legume pod borer, Maruca vitrata (Fab) (Lepidoptera: pyralidae) on cowpea in Nigeria. Production Ecology, 5, $245-251$.

Jackai, L. E. N. (1993). The use of neem in controlling cowpea pests. IITA Research, 7, 5-11.

Jackai, L. E. N., \& Singh, S. R. (1988). Screening Techniques for Host Plant Resistance to Insect Pests of cowpea. Tropical Grain Legume Bulletin, 35, 2-18.

Job, T. A., Maner, J. H., \& Buitrago, J. (1983). Nigerian journal of Nutritional Sciences, 4(1), 29-34.

Karungi, J., Adipala, E., Kyamanywa, S., Ogenga-Latigo, M. W., Oyobo, N., \& Jackai, L. E. N. (2000). Pest Management in Cowpea. Part 2. Integrating planting time, plant density and insecticide application for management of cowpea field insect pests in eastern Uganda. Crop Protection, 19, $237-245$. http://dx.doi.org/10.1016/S0261-2194(00)00013-2

Litsinger, J. A., Quirino, C. B., Lumaban, M. D., \& Bandong, J. P. (1977). Grain Legume Pest Complex of Three Phillipine Rice-Based Cropping System. Cropping Program, IRRI, Los Banos. Philippines,

Okigbo, B. N. (1978). Grain legumes in the agriculture of the tropics. In Pests of Grain legumes Ecology and control (Edited by Singh S.R. Van emden H.E. and Taylor T.A) Academic Press, Inc., New York. 
Omongo, C. A., Adipala, E., Ogenga Latigo, M. W., \& Kyamanywa, S. (1997). Insecticide application to reduce pest infestation and damage on cowpea in Uganda. Afri. Plant Protion. 4(2), 91-100.

Oparaeke, A. N., Dike, M. C., \& Amatobi, C. I. (2006). Botanical Pesticide Mixtures for Insect Pest Management on Cowpea, Vigna unguiculata (L) Walp Plants-The Legume Flower Bud Thrips, Megularothrips sjostedti Trybon.

Rachie, K. O. (1985). Introduction. P. xxi xxviii. Cowpea research, production and utilization. Wiley. New York.

Remison, S. U. (1978e) Cowpea agronomy works at National Cereals Research Institute. Paper presented at the 1st National meeting. On development of package. Recommendations for legume crops at N.C.R.I, Ibadan,

Remison, S. U. (2005). Arable and vegetable crops in the tropics. Lift Print Associate. pp. 4-18.

Tobih, F. O. (2007). Control of yam beetle Heteroligus meles Bilb (Coleoptera. Dynastidae) in the rain forest zone of the upper Niger Delta, Nigeria. Ph.D thesis, Delta State University, Abraka. p. 49. 